Hyperboreus", a kind of repository of contemporary inventions and experiments. In the same year Charles XII made him assessor in the College of Mines. His writings from that time onwards, published and unpublished, ranged over the whole field of science. In 1721 he wrote his "Prodromus Principiorum Rerum Naturalium", in 1722, a work on geology, in 1734 published in three volumes his "Opera Philosophica et Mineralia", in 1741 his "Economy of the Animal Kingdom" and in 1744-45 his "Animal Kingdom", with which his course as a natural philosopher ended. In London in 1749-56 he published his "Heavenly Arcana" and this was followed by some two score of theological works. $\mathrm{He}$ himself made no attempt to found a sect, but his followers established "the New Church signified by the New Jerusalem in the Revelation" and "Sweden. borgians' are to-day found all over the world.

THE removal of Swedenborg's body to Sweden in 1908 was but a part of a movement for the recognition of his genius as a man of science. In 1901 Dr. Max Neuberger, of Vienna, gave an address to an assembly of German naturalists and physicians entitled "Swedenborg's References to the Physiology of the Brain", in which he pointed out how Swedenborg had anticipated many modern discoveries. Dr. Neuberger next addressed a communication to the Academy of Sciences of Stockholm in which he expressed his regret that Swedenborg's manuscript on the brain had not been published. A committee was appointed to investigate the matter. On May 29, 1903, Prof. Gustaf Retzius, the president of the Academy, presented a report on the investigation to the Congress of Anatomists at Heidelberg. This led to a further examination of the manuscripts, and Dr. Retzius proposed that the Academy should issue an edition of Swedenborg's scientific and philosophical works. Even before this, proposals had been put forward for the founding of a museum for the preservation of portraits, relics and other Sweden. borgiana. Emerson wrote of Swedenborg: "He had great modesty and gentleness of bearing. His habits were simple; he lived on bread, milk and vegetables ; he lived in a house situated in a large garden. . . . $\mathrm{He}$ is described, when in IJondon, as a man of a quiet, clerical habit, not averse to tea and coffee, and kind to children. He wore a sword when in full velvet dress, and whenever he walked out carried a goldheaded cane. There is a common portrait of him in antique coat and wig, but the face has a wandering or vacant air."

\section{Scientific Delegation to India}

OUR correspondent, writing from Bombay on January 15, says: Some sixty members of the scientific delegation to India, including the president, Sir James Jeans, embarked on the S.S. Strathaird at Bombay on January 15 for the homeward voyage. Of these, nearly all had made the whole or part of the tour in Southern India arranged to take place after the Congress in Calcutta. This tour embraced visits to Madras, Mysore, and Bangalore, which none would willingly have missed. After a hot journey south, Madras received the delegation with a very perfect day, during which the University gave a luncheon, and most of the delegates attended a garden party arranged by the city in honour of the Viceroy. The small but very attractive aquarium, and other points of interest, were visited. The wonders of Mysore will never be forgotten by the visitors. They were received as guests of the State throughout their too short sojourn and were shown many of the institutions which are there maintained by an enlightened Government, while when darkness fell they viewed with amazement the illuminated fountains at the great power dam on the Cauvery, and the blaze of lights from the city as seen from Chamundi Hill. At Bangalore the Indian Institute of Science and other institutions were visited, and the party was entertained to tea by the Dewan Sahib of Mysore.

"AT all three cities visited during this southern tour, as indeed at every city visited throughout India, members of the delegation have freely responded to the many calls upon them for lectures, and all, whether so occupied or not have had constant opportunity for the renewal of contacts with old students now occupying responsible positions in the places visited, and for making new acquaintanceships with workers in their various fields of interest. The whole spirit of the visit has been one of mutual and practical help, and nothing has impressed us more than the immense interest of the community in the delegation, and especially that of the students who have thronged the lectures and incidentally demanded of us inconceivable numbers of autographs. The visit has been said, by many influential Indians, to have been a great event for India : certainly it has been so for the delegation."

\section{Museums and the Research Worker}

Some aspects of recent criticism of ethnographical collections in the museums of Great Britain are considered on p. 179 of this issue of Nature. It cannot be emphasized too frequently that the great national collections-the question under discussion cannot affect the smaller museums except in so far as they are prepared to specialize-being supported out of public funds, it is their bounden duty to perform a function of public utility; whether that may be, as is now generally required of them, that they should take their share in making efficient and supplementing the machinery of general education, or the more highly specialized function of assisting the research worker. To the latter rather than to an attachment to a traditional system must be attributed the classificatory organization which has been subjected to criticism. For it must not be forgotten that the great national collections, as well as the smaller ethnographical museums, some highly specialized, such as the Pitt-Rivers Museum at Oxford, the Museum of Archæology and Ethnology at Cambridge, or the Manchester University Museum, have been the laboratories for the scientific researches of the 